\title{
LOUISIANA AND QUEBEC TERMINOLOGY AS A TOOL IN POLISH-ENGLISH LEGAL TRANSLATION
}

\begin{abstract}
While in the majority of English-speaking territories the dominant legal tradition is common law, in Louisiana and Quebec the native language is English and the legal system stems from continental civil law. Both the Louisiana Civil Code and the Civil Code of Quebec take root in the European codification movement, following Code Napoleon. Bearing in mind the link between law and language, these jurisdictions provide a unique source of English civil law terminology with well-founded conceptual background.

The civil codes of Louisiana and Quebec seem to be potentially useful for the translation of Polish private law into English. Yet there are some reservations which should be considered. By comparing two different translations of Article 292 of the Polish Civil Code, this paper is intended to contribute to the debate on the use of Quebec and Louisiana terminology in Polish-English legal translation.
\end{abstract}

Keywords: Polish-English legal translation, legal language, civil law terminology, Louisiana law, Quebec law

\section{Introduction}

Both the common law system and the English language are originally bound with the tradition of England. Yet the legal system and the language spread throughout the world, and became adopted over large parts of it. Although in the majority of English-speaking territories the dominant legal tradition is common law, there are several jurisdictions where the native language is English and the original legal system is based on continental civil law. This creates a unique situation where the English language originally serves the purposes of law which is similar in nature to the law used on the European continent, including Poland. Hence a question can be raised of whether the legal language of Louisiana and Quebec could be useful for Polish-English legal translation. In this paper the applicability of English 
civil law terminology has been researched on the basis of a comparison between two different translations of Article 292 of the Polish Civil Code. The conclusions reached as a result of the comparative analysis are intended to contribute to answering the question posed above.

\section{Why does the connection between a legal system and language matter?}

The connection between language and a legal system is crucial due to the fact that "language is the vehicle for law, its concepts and institutions. There is an almost constant exchange of thoughts, words and terms between language and legislation" (Pieńkos 1999: 23). In actual fact, language transmits messages connected with law and facts of legal significance (Mattila 2001: 33). Moreover, to understand the uniqueness of the bond between law and language, it is necessary to make a reference to culture. In terms of diffusion, culture is believed to consist of spheres such as everyday life, science, religion, economy, an administrative-legal sphere and a communication-linguistic sphere. The last two are unique in such a way that they infiltrate all other spheres and sustain them (Gajda 2004). They also permeate each other.

Because of the close link between language, the institutions of society and culture, the original civil law concepts expressed in Louisiana and Quebec in English have the importance of being authentically embedded in the legal culture of these jurisdictions. Thus they have a well-established conceptual background. When the fact is considered that many European languages, including Polish, express the concepts of European civil law tradition in a similar way, a question may be asked whether in Louisiana and Quebec there are equivalent concepts to the European, and whether they are applicable in translation.

\section{Notional framework of the civil law and common law traditions}

The conceptual frameworks which underlie the common law and civil law traditions differ significantly. Having received Roman law, Romancespeaking countries, Germanic countries and through them other countries developed similar terminology, institutions and legal principles. In turn, a distinctive conceptual apparatus and set of principles, often without 


\section{Louisiana and Quebec Terminology as a Tool in Polish-English Legal...}

a counterpart in civil law systems, have been created in Anglo-Saxon law (Morawski 2009: 70).

The very basic difference between the notional underpinning of the systems based on common law and civil law is that the former is case-based while the latter is abstract. The study of law on the Continent has always belonged to higher education at universities. The adoption of Roman law was scholarly in character, which led to the importance of doctrines, containing systematic accounts and discussion of the broad legal principles. Such an approach is a necessity for an analytical and systematic understanding of law. Civil law is characterised by a high level of abstraction and striving for coordination of the legal subject matter (Dainow 1967: 419435). It is focused on attempts to create an ideal legal system, understood as a set of norms which are ordered and suited to citizens' needs (Tokarczyk 2001: 159). Common law, on the contrary, has an added empirical flavour by handling particular cases. This eliminates the idea that law is a set of highly systematised rules and contributes to the distinctive model of legal thinking. At the same time England had lacked law faculties until the late $19^{\text {th }}$ century (Samuel in Smits 2006: 149-158). The doctrine in common law is rather concerned with analysing particular cases and the distinguishing rules they express (Dainow 1967: 419-435). "Common law is deeply embedded in the cultural reality of social life", and thus norms in this tradition are not abstract and general, but govern a given case (Tokarczyk 2001: 159).

As a result of the above divergence, common law and civil law are ordered according to totally different structures. In the civil law tradition, law is horizontally divided into branches. The basic distinction is drawn between private law, concerning mainly relationships between citizens, and public law, which involves relationships where the state is a party. Further divisions are made, and, in the case of public law, constitutional, criminal, administrative, financial and procedural branches are distinguished (Morawski 2009: 78-79). In the common law tradition the division of law into branches has not been highlighted by the judiciary. Nor do the legal scholars place so much emphasis on the branches of law as their civil law counterparts do. The basic division is drawn between norms which belong to common law (as developed by the royal courts) and equity (Tokarczyk 2001: 160). The distinction between public and private law as well as other categorisations have not been sharply drawn (Samuel in Smits 2006: 155; Cruz 1999: 44). The basic unit of law is an institution and it plays a crucial role in the common law tradition (Tokarczyk 2001: 160). An institution is "a complex of norms which constitute a functional whole 
and regulate some typical set of social relations" such as marriage or mortgage (Morawski 2009: 75).

Distinct concepts which underlie the common law and civil law traditions translate into different conceptual frameworks. (Morawski 2009: 7879). Even if similar solutions to the same social problems have been devised both by the civil law and common law traditions, the methods used are divergent. Each of the systems possesses its own distinctive and comprehensive nature, which contributes to its individuality (Dainow 1967: 419-435). There are in fact two distinct modes of thinking. As Cruz (1999: 104) puts it, while civil law judges "think in terms of solutions to problems, derived from systematic and authoritative expositions of the law and work towards solutions, from general clauses and principles, English law judges see their primary function as the arbiters of disputes and that their task is to resolve disputes".

\section{The law of Louisiana}

Considered a traditional mixed jurisdiction, Louisiana is the only state of the United States which belongs (in terms of private law) to the civil law tradition. The state possesses a civil code which stems from the $19^{\text {th }}$ century European codification movement. Unsurprisingly, Louisiana is referred to as a civil law island surrounded by the sea of common law. The inhabitants of this territory, which before the Louisiana purchase of 1803 had belonged to Spain and France, favoured the law that suited them from a cultural and economic perspective, and under which they had obtained property rights (Parise 2013: 429-430, 453).

The first Louisiana Civil Code was enacted in 1808 and drew from French sources (Code Napoleon itself or its draft) and some very significant parts of the code are rooted in Spanish law (Barham 1976: 474-494). Most importantly, the code was enacted in French and translated. The same happened to the revised code of 1825. Constitutionally imposed, the English language gradually ousted French in the state and the 1870 Louisiana Revised Civil Code was promulgated only in English, still following the translation of 1825 (Bermann 2006, 89-102). That version, continually revised, with amendments mainly from the second half of the $20^{\text {th }}$ century, is what the current text of the code comes from (Parise 2013: 432-433).

Of particular interest is the translation experience Louisiana gained. In fact, the problems faced were of not only translation between languages, but also between systems. The translation of the code was referred to as being 
"spectacularly bad" and was accused of lacking clarity. This resulted in the courts' resort to the French version, which was consistently preferred over years. The situation did not change after the enactment of the English-only code of 1870. Bermann (2006: 89-102) cites a case from 1998, where the court directly resorted to the model provision of Code Napoleon.

\section{The law of Quebec}

Canada sets an important example from the perspective of the legal translation as its long-standing bilingualism is assisted by a constitutional principle that legislation should be published both in French and English and that the two versions are equally authentic (Šarčević 1997: 43). Moreover, one of the provinces, Quebec, is considered a mixed jurisdiction, which joins the elements of the common law and civil law traditions (McAuley 2012: 354), its private law being rooted in French civil law. Prior to the British conquest, the area had been governed solely by French legislation. The preservation of civil law was on the one hand related to the economic interests of the population (Goulet 1980: 354-378) and on the other to ethnographic factors, namely the inhabitants' will to retain their French culture (Richert 1973: 501-520).

As a result of codification, in 1866 the Civil Code of Lower Canada was put into force. The code was not a mere copy of Code Napoleon and it embraced local elements, British common law and Louisiana Civil Code (Goulet 1980: 354-378). The code was supposed to be drafted simultaneously in French and English and the staff appointed to write it was bilingual. Yet in reality drafting took place in French at first and then the text was translated. In fact, the Louisiana Civil Code served more as a linguistic model than a substantive one (Richert 1973: 501-520). The translation was literal, containing borrowings, calques and some false cognates. The code had undergone amendments (Goulet 1980: 354-378) until it was repealed by the new Civil Code of Québec of 1991.

The new code is in fact a re-codification, involving "substantial reform of the content and a re-tooling of the language". It aims to detach itself from history so as to be "free-standing, self-sufficient and autonomous, enhancing the feeling of distinctiveness and maturity of Quebec society" (Brierley 1992: 484-503). It is important to notice that the enactment of the code took place after the campaign aimed at purifying the language of legislation. The reforms in Canadian legislation, which were aimed at ensuring the equal status of French and English, took place after two centuries of domina- 
tion by literal translation in the country (Šarčević 1997: 43-48). Praised for the clarity in ordering the subject matter, the new code is divided into ten books, which is different from the traditional layout of such codes (Brierley 1992: 484-503).

\section{The comparison of the use of civil law and common law terminology in Polish-English legal translation}

In the existing translations of the Polish Act of 23 April 1964 - the Civil Code, the application of both common law and civil law terminology may be discerned. This gives the opportunity to compare the effectiveness of the translation of the same provision of the code with the use of different sets of terminology. In the course of the analysis it is necessary to remember that a legal translator's task is to produce a text which conveys the author's intent, namely the meaning and effect intended by the author (Šarčević 1997: 72-73). Collectively, these could be grasped as the legal sense. Hence the legal translator's major goal which determines the success of legal translation is to convey the legal sense from the source text to the target text.

As an example, Art. 292 of the Polish Civil Code will be analysed in the translations released by two leading legal publishers.

Table 1

Comparison of two translations of Art. 292 of the Polish Civil Code

\begin{tabular}{|c|c|c|}
\hline Original text & $\begin{array}{l}\text { Kodeks Cywilny. } \\
\text { Civil Code. } \\
\text { Wolters Kluwer }\end{array}$ & $\begin{array}{c}\text { Kodeks Cywilny. } \\
\text { The Civil Code. } \\
\text { C.H. Beck }\end{array}$ \\
\hline Art. 292. & Article 292. & Art. 292. \\
\hline $\begin{array}{l}\text { Służebność gruntowa może } \\
\text { być nabyta przez zasiedze- } \\
\text { nie tylko w wypadku, gdy } \\
\text { polega na korzystaniu } \\
\text { z trwałego i widocznego } \\
\text { urządzenia. Przepisy o naby- } \\
\text { ciu własności nieruchomości } \\
\text { przez zasiedzenie stosuje się } \\
\text { odpowiednio. }\end{array}$ & $\begin{array}{l}\text { Land servitude may be ac- } \\
\text { quired by acquisitive pre- } \\
\text { scription only in the case } \\
\text { where it consists in making } \\
\text { use of a permanent and vis- } \\
\text { ible installation. Provisions } \\
\text { on acquisition of ownership } \\
\text { of immovable property by } \\
\text { acquisitive prescription shall } \\
\text { apply accordingly. }\end{array}$ & $\begin{array}{l}\text { An easement appurtenant } \\
\text { may be acquired by ad- } \\
\text { verse possession only if it } \\
\text { consists in the use of a per- } \\
\text { manent and visible facility. } \\
\text { The provisions on acquir- } \\
\text { ing real estate ownership } \\
\text { by adverse possession apply } \\
\text { accordingly. }\end{array}$ \\
\hline
\end{tabular}


Having compared the translations of the above provisions, three divergent choices of terminology can be identified.

\section{Służebność gruntowa: land servitude or easement appurtenant}

The term servitude used by the first translator stems from the civil law tradition and is used in Louisiana Civil Code and the Civil Code of Québec. Pursuant to Art. 646 of Louisiana Civil Code "a predial servitude is a charge on a servient estate for the benefit of a dominant estate. The two estates must belong to different owners". The definition of a predial servitude is very similar the definition of stużebność gruntowa stipulated in Art. 285 of the Polish Civil Code. There are several synonymous terms for a predial servitude, which can be deemed as equivalent to Polish stużebność gruntowa: servitude appurtenant, real servitude, predial servitude and landed servitude (Garner 2004: 1401). The term land servitude, which is not used in the source language, seems to be a calque from Polish, but remains clear as to its meaning. The concepts of servitude and stużebność are very similar in Polish, Louisiana and Quebec law. For instance, it is possible to divide servitudes affecting land as either personal or real. Personal servitudes benefit a particular person and terminate upon the death of this person. Real servitudes benefit the owner of one estate through some use of a neighbouring estate (Lehman and Phelps 2008). Interestingly, the concept of personal servitudes as stipulated in Art. 532 of the Louisiana Civil Code differs from the Polish concept of stuizebność osobista. The provision states that "a personal servitude is a charge on a thing for the benefit of a person. There are three sorts of personal servitudes: usufruct, habitation, and rights of use". In Polish law usufruct is not considered as a servitude, but a separate real right. Still, the characteristics of a predial servitude and its Polish counterpart are highly equivalent, which seems to justify the use of the civil law term in translation.

The second translator applied a common law equivalent easement appurtenant. It is defined as "an easement created to benefit another tract of land, the use of easement being incident to the ownership of that other tract" (Gray 2011: 234-239). Referring to the concept of an easement in the common law tradition, it can be understood as a right of use over the property of another. Easements can be divided into an easement appurtenant, created for the benefit of adjoining lands, and an easement in gross, existing for the benefit of a specific individual. An easement appurtenant, which at- 
taches to the land permanently, benefits its owner. The existence of this easement is conditioned upon the existence of two pieces of land owned by different individuals. The dominant estate is benefited by the easement while the servient estate bears the burden. An easement appurtenant is incapable of a separate existence from the land to which it is annexed. In turn, an easement in gross is not appurtenant to any estate. It is personal to the holder and hence does not run with the land (Lehman and Phelps 2008). Analysing the above characteristics, it is possible to reach a conclusion that the institution of an easement is equivalent to a servitude and in turn to the corresponding institution in Polish law. Therefore, in translation easement appurtenant seems to be a proper term for stużebność gruntowa, despite its common law origin.

\section{Zasiedzenie: acquisitive prescription or adverse possession}

The term used by the first translator, acquisitive prescription, is defined as "the acquisition of title to a thing (...) by open and continuous possession over a statutory period" (Garner 2004: 1220). This is a term used in both Louisiana and Quebec. Notably, the term does not only appear in civil law, but it is also present in the common law tradition. It is underlined that prescription is similar to adverse possession. Prescription is a way to acquire title to real property by occupying it for a period of time but the title acquired under it is presumed to have resulted from a lost grant. In the past a right could only be acquired prescriptively at common law if a person could demonstrate that they had used a land for 'time immemorial'. The year 1189 was fixed as the limit of legal memory and any right enjoyed at that date was unchallengeable. As it was impossible to demonstrate this in practice, the fiction of a lost modern grant had been devised by the middle of the $19^{\text {th }}$ century. This meant that in the situation where enjoyment of the right to land for 20 years could be shown, the mere fact that the enjoyment might not have existed in 1189 did not bar the operation of the prescription. The courts accepted that the enjoyment had arisen as a result of a grant that had later been lost (Stewart 2006). In the Louisiana Civil Code, acquisitive prescription is defined without any reference to the common law origin of the term. Furthermore, Art. 742. states that an apparent servitude may be acquired by peaceable and uninterrupted possession of the right for ten years in good faith and by just title. It may also be acquired by uninterrupted possession for thirty years without title or good faith. Notably, 
acquisitive prescription does not only apply to the acquisition of ownership, but it also refers to servitudes, both in Louisiana and Quebec.

The second translator decided to use a common law equivalent adverse possession. Present in English legislation (Limitation Act 1980), adverse possession denotes "the acquiring of title to real property owned by someone else by means of open, notorious, hostile and continuous possession for a statutory period of time" (Reilly 1993: 13-15). In order to acquire title to land by adverse possession the statute of limitations for ejectment must lapse, which bars the institution of a lawsuit by the true owner. The key to this institution is the occupant's intent to claim and hold real property in opposition to anyone else, which is demonstrated by visible and hostile possession of the land. The notion underlying adverse possession is that the title to land must be certain. The owner who has not protected the land by his or her own fault and neglect loses it in favour of an adverse possessor who has treated the land as their own for a required period of time. The completion of adverse possession leads to the adverse possessor having full legal title to the property. Thus, the adverse possessor is considered the original owner of the land and has the right to use it in any lawful way. Moreover, like in Polish law, common law provides for a related concept referring to the acquisition of easements: easement by prescription. It arises through an individual's use of land as opposed to its possession. For instance, if one person creates and openly uses a right of way across another person's land without their permission for a statutory period of time, an easement by prescription is created (Lehman and Phelps 2008).

The analysis of the conceptual background behind both terms allows for a conclusion that the institutions of acquisitive prescription and adverse possession are virtually equivalent. In actual fact both of them take root in common law, but the Louisiana and Quebec concept of acquisitive prescription has been appropriated by the civil law systems of these jurisdictions. Furthermore, it could be inferred that both terms acquisitive prescription and adverse possession effectively reflect the meaning of zasiedzenie as understood in Polish law (Art. 172-176 of the Polish Civil Code).

\section{Nieruchomości: immovable property or real estate}

The first translator used a term immovable property, which corresponds to the terminology present in Louisiana and Quebec law. Art. 899 of the Civil Code of Quebec sets forth that "property, whether corporeal or incorporeal, 


\section{Przemystaw Kusik}

is divided into immovables and movables". Further provisions (Art. 900904) define the nature of immovables. Immovables encompass land and any constructions and works of a permanent nature located on the land as well as anything forming an integral part of the land. If plants and minerals are not separated from the land, they are also immovables. Movables which lose their individuality by incorporation with immovables, ensuring the utility of the latter, form an integral part of the immovables. Most importantly, the Code states that real rights in immovables, as well as actions to assert such rights or to obtain the possession of immovables, are immovables as well. It can be noted that immovables include things immovable by their own nature, which cannot move themselves or be removed from one place to another, and also those which become immovables by the destination of the law. Seeds, plants and fodder which have been placed upon land are immovables by destination. An instance of an immovable is also a servitude established on land (Bouvier 1856).

The second translator's common law term real estate is defined as "the physical land at, above and below the earth's surface with all appurtenances, including any structures; any and every interest in land whether corporeal or incorporeal, freehold or non-freehold; for all practical purposes, the term real estate is synonymous with real property" (Reilly 1993: 326). The term is also considered as synonymous with real property by Garner (2004: 1254). Still, there are opinions excluding incorporeal property from the concept of real estate and in that case it is defined as "land, improvements and buildings thereon, including attached items and growing things. It is virtually the same as real property, except real property includes interests which are not physical such as a right to acquire the property in the future" (Hill and Hill 2002). Real estate is considered a modern term (Lehman and Phelps 2008). Nonetheless, it is worth referring to the basic concept of real property, which reveals the conceptual background behind the way land has been understood in English law. Namely, real property encompasses all land, structures, firmly attached and integrated equipment as well as anything growing on the land. Moreover, all interests such as the right to future ownership, the right to occupy for a period of time, the right to get the property back if it ceased to be used for its current purpose or an easement are also categorised as real property. As a group of rights, real property is compared to a bundle of sticks which can be divided (Hill and Hill 2002). Real property may be categorised as corporeal or incorporeal. The former includes substantial and permanent objects, which in general can be referred to as land. Some chattels which are annexed to land are also deemed a part of it. Even money agreed to be laid out in land is regarded as real property. In- 
corporeal property comprises inheritable rights which are not land. Yet by their own nature or use they are annexed to corporeal inheritances, out of which they issue or which they pertain to (Bouvier 1856).

In Polish law, things, including immovables, may only be corporeal. Therefore, it could be concluded that corresponding concepts in both target texts differ from the source text in this respect. Although incorporeal property is sometimes disregarded in the definition of real estate (as opposed to real property), it is still visible that a different philosophy understands the understanding of rights to land in the common law tradition. Nonetheless, Art. 45 of the Polish Civil Code expressly stipulates that incorporeal property is excluded from the concept of things, which seems to remedy this problem, especially when the target audience receives the translation of this provision as well. Even if the conceptual framework behind the common law term is more divergent than the one behind the civil law term, this does not seem to affect the translation here. The reference of real estate or real property to land seems to be sufficiently clear to reflect the meaning of nieruchomość. Notably, the context and wording of Polish law seem to amend the inconsistencies discussed above. Thus, the knowledge of this aspect of law would be beneficial to the target audience. Consequently, despite some reservations, both terms might be used as partial equivalents of nieruchomość.

\section{Conclusions}

In respect to Polish-English legal translation, the Louisiana Civil Code and the Civil Code of Quebec could be considered as useful tools in terms of the translation of Polish civil law (in the sense of private law) into English. The terms used in the codes of Louisiana and Quebec may turn out to be closer in meaning to the corresponding Polish terms than those derived from common law. This is because of the unique coincidence of the private law system being based on civil law and the English language being native to the inhabitants of Louisiana and Quebec. In view of the significance and consequences of the link between law and language, civil law English terminology with a well-grounded conceptual framework is a unique repository of potential equivalents which can be applicable in translation. Not denying the above statement, there are a few reservations which ought to be taken into account before an equivalent from English-language civil law is used. At first, the codes derive from old translations of their original French texts and there were problems with the applied terminology. Secondly, as 


\section{Przemystaw Kusik}

in case of any other legal translation, concepts seeming similar have to be examined, especially because common law regions have exerted influence over the regulations in the English-speaking civil law jurisdictions. Moreover, one has to remember that Polish law has moved towards German law in the civil law family, which may also lead to inconsistencies between its concepts and the concepts present in Louisiana and Quebec, where French law was the model. Thirdly, the territorial range of Louisiana and Quebec law, and thus the popularity of its terminology, is limited. The territories of Louisiana and Quebec are relatively small compared to the area in which civil law is the dominant legal tradition. There are websites explaining the content of civil law to English speakers from other jurisdictions, which suggests that the particulars of this legal system are not universally known to those living outside it. Nonetheless, one should remember that the English common law terminology ought to be approached with even greater care, as differences in the conceptual background between it and civil law terms are much more likely to occur.

The analysis undertaken in this paper does not resolve the issue over which source of terminology is more suitable for Polish-English legal translation. If an answer to this question is feasible, it will require not only a comprehensive analysis of the transmission of the legal message, performed on a much bigger sample of double translations, but probably also collecting feedback from prospective target readers of such translations. Yet an important fact has been demonstrated that in translation it is possible to use either civil law or common law terminology without affecting the quality of the target text. In the examples presented above the use of both types of terminology allows for achieving the goal of legal translation, namely the transmission of the legal message between the source text and the target text. In actuality, there are advantages and disadvantages with both alternatives in the terminology, but the choice of either of them could be equally successful.

One more aspect of the possibility to choose between civil law and common law terminology needs to be discussed, namely consistence in the use of a given set of terms. Having decided on the application of common law terminology, it would seem to be advisable not to mix it with civil law terms in a single translation. This would prevent the target audience from being confused by a variety of terminology having its origin from multiple sources. However, such consistence might not be fully attainable. In the translations of the Polish Civil Code published by C.H. Beck and Wolters Kluwer one can meet terms which come from both common law and civil law traditions. Although such a practice should not be abused, in some situations it seems 
to be unavoidable. Following common law terms in general, a translator may face a situation where no common law equivalent would be suitable enough for a Polish concept. For instance, in the case of the term użytkowanie, which denotes a limited real right present only in civil law jurisdictions, there seems to be no better equivalent than usufruct. Being a civil law term used in Louisiana and Quebec, usufruct has also been applied in the translation by C.H. Beck, which generally uses common law equivalents to translate Polish property law.

Not prejudging which source of terminology is objectively more conducive to Polish-English legal translation, it should be underlined that a decision over which of the equivalent terms to be used should be preceded by consideration of its conceptual background. It is important to carefully verify the meaning of an equivalent (and thus its potential to fulfil its purpose) and its transposition to the target text. This requires both proper understanding of the underlying conceptual background of terms and the evaluation of their applicability to the source law. It is necessary both in the case of common law and civil law English terms, which can equally differ from the corresponding Polish concepts. Should the analysis reveal that both types of terms achieve the goal of legal translation, it will be up to the translator's preferences which equivalent to apply. A reasonable level of consistence in the use of either civil law or common law terms within a translation would be advisable. Nonetheless, it is the distortion of the legal message by the avoidance of errors that actually determines the quality of the target text. The terminology's source does not seem to be decisive in this respect.

\section{R E F E R E N C E S}

Barham, M. 1976. 'Methodology of the Civil Law in Louisiana.' Tulane Law Review, 50: $474-494$.

Bermann, G. 2006. 'Bilingualism and Translation in the U.S. Legal System: A Study of the Louisiana Experience.' American Journal of Comparative Law, 54: 89102.

Bouvier, J. 1856. A Law Dictionary, Adapted to the Constitution and Laws of the United States. Philadelphia: Childs \& Peterson.

Brierley, J. 1992. 'The Renewal of Quebec's Distinct Legal Culture: The New Civil Code of Québec.' The University of Toronto Law Journal, 42(4): 484-503.

Cruz, P. de. 1999. Comparative Law in a Changing World. London/Sydney: Cavendish Publishing Limited.

Dainow, J. 1967. 'The Civil Law and the Common Law: Some Points of Comparison.' The American Journal of Comparative Law, 15 (3): 419-435. 
Gajda, S. 2004. 'Język administracyjno-prawny w perspektywie językoznawczej i prawoznawczej' in E. Malinowska (ed.) Język - Prawo - Społeczeństwo, 19-31. Opole: Wydawnictwo Uniwersytetu Opolskiego.

Garner, B. (ed.). 2004. Black's Law Dictionary. Thomson West.

Goulet, J. 1980. 'The Quebec Legal System.' Law Library Journal, 73: 354-378.

Gray, K. and Gray, S. 2011. Land Law. Oxford: Oxford University Press.

Hill, G. and Hill, K. 2002. The People's Law Dictionary. MJF Books.

Lehman, J and Phelps, S. (eds.). 2008. West's Encyclopedia of American Law. Detroit: Thomson/Gale.

Mattila, H. 2006. Comparative Legal Linguistics. Ashgate.

McAuley, M. 2012. 'Quebec' in V. Palmer (ed.) Mixed Jurisdictions Worldwide: The Third Legal Family, 354-380. Cambridge: Cambridge University Press.

Morawski, L. 2009. Wstęp do Prawoznawstwa. Toruń: Dom Organizatora.

Parise, A. 2013. 'Private Law in Louisiana: An Account of Civil Codes, Heritage, and Law Reform' in J. Rivera (ed.) The Scope and Structure of Civil Codes, 429-454. Heidelberg/New York/London: Springer.

Pieńkos, J. 1999. Podstawy juryslingwistyki. Język w prawie - prawo w języku. Warszawa: MUZA SA.

Reilly, W. 1993. The Language of Real Estate. Chicago: Real Estate Education Company.

Richert, J. and Richert, E. 1973. 'The Impact of the Civil Code of Louisiana upon the Civil Code of Quebec of 1866.' Revue Juridique Themis, 8 (3): 501-520.

Samuel, G. 2006. 'Common Law.' in J. Smits (ed.) Elgar Encyclopedia of Comparative Law, 145-160. Cheltenham/Northampton: Edward Elgar.

Šarčević, S. 1997. New Approach to Legal Translation. The Hague/London/Boston: Kluwer Law International.

Stewart, W. 2006. Collins Dictionary of Law. Glasgow: Collins.

Tokarczyk, R. 2001. Wspótczesne Kultury Prawne. Kraków: Kantor Wydawniczy Zakamycze.

\section{Source Texts}

Kodeks Cywilny. Civil Code. 2011. Warszawa: Wolters Kluwer.

Kucharska, E. 2015. Kodeks Cywilny. The Civil Code. Warszawa: C.H. Beck.

Limitation Act 1980 (c. 58).

Louisiana Civil Code.

The Act of 23 April 1964 - the Civil Code. Journal of Laws of 1964, no. 16, item 93, as amended.

The Civil Code of Quebec. 